\title{
Makna Citra Diri Perempuan Bertato yang Berhijab
}

\author{
Callista Renata Yasim, Diah Ayu Candraningrum \\ callista629.cr@gmail.com,diahc@fikom.untar.ac.id \\ Fakultas Ilmu Komunikasi Universitas Tarumanagara
}

\begin{abstract}
Tattooing is one of the manifestations of artifactual communication. Artifactual communication is a form of non-verbal communication that takes place through various artifacts, in this case including tattoos drawn in a person's body, which can convey a message to those who witness and give statements about the wearer. controversial phenomena occur and contradict the stigma of hijab behind this with the presence of a girl with a tattoo on the forehead suddenly became the concern of Warganet through the photos uploaded to social media. This study uses qualitative methods and the results show that tattooed women and wearing hijab have their own meanings and self-image in society. The presence of tattoos that have caused a woman's self image to be negative even though it has been veiled and also has an impact on comments - it is the pros and cons.
\end{abstract}

Keywords: Tatto, Hijab, Self Image

\begin{abstract}
Abstrak
Tato adalah salah satu manifestasi dari komunikasi. Komunikasi artifaktual adalah bentuk komunikasi non-verbal yang berlangsung melalui berbagai artefak. Dalam hal ini termasuk tato yang digambar dalam pesan tubuh seseorang dan ditujukan kepada mereka yang menyaksikan dan memberikan pernyataan tentang fenomena kontroversial ini. Pemakai tato bertentangan dengan stigma jilbab, namun kemudian hadir seorang gadis dengan tato dahi yang tiba-tiba menjadi perhatian warganet melalui foto-foto yang diunggah ke media sosial. Penelitian ini menggunakan metode kualitatif. Hasil penelitian menunjukkan bahwa wanita yang bertato dan mengenakan jilbab memiliki makna sendiri. Dan citra diri di masyarakat dengan kehadiran tato yang telah menyebabkan citra diri wanita menjadi negatif. Meskipun telah terselubung dan juga berdampak pada komentar pro dan kontra.
\end{abstract}

Kata Kunci: Tato, Hijab, Citra Diri

\section{Pendahuluan}

Citra diri menurut Mangkuprawira (dalam Pipit, 2013) adalah sikap seseorang terhadap tubuhnya secara sadar. Sikap ini mencakup persepsi dan perasaan tentang ukuran, bentuk, fungsi, penampilan, potensi tubuh saat ini dan masa lalu yang berkesinambungan dimodifikasi dengan pengalaman yang baru yang memengaruhi perilaku dan perilaku memengaruhi performa.

Penampilan seseorang menurut Hartono (dalam Pipit, 2013) adalah citra fisik, yang biasanya dilihat adalah tinggi rendahnya orang itu, warna kulitnya, parasnya cantik dan tampan, gemuk kurus, pakaiannya rapi lusuh dan lain sebagainya. Citra fisik ini paling mudah dikenali karena nampak pada permukaan luar diri. Penampilan adalah suatu bentuk citra diri yang terpancar pada diri seseorang dan merupakan sarana komunikasi diri dengan orang lain. Penampilan adalah pembentukkan diri seseorang baik secara fisik maupun kepribadian yang baik sehingga dapat menimbulkan daya tarik bagi orang yang memandangnya (Fitriana, 2012). 
Tato telah menjadi sebuah fenomena yang disukai oleh sebagian masyarakat umum, termasuk wanita. Bila masyarakat mulai menerima keberadaan pria yang memiliki tato (misalnya pada kalangan preman atau geng motor), namun lain halnya dengan wanita yang memiliki tato. Tapaningtyas (2008) menyebutkan bahwa pandangan masyarakat terhadap wanita bertato $55,45 \%$ negatif, $12,22 \%$ positif, dan $32,33 \%$ netral. Kebanyakan orang menilai wanita yang mentato tubuhnya identik dengan hal yang negatif (sangar, menyeramkan, preman, perempuan nakal, liar). Hal ini senada dengan penelitan Amstrong dkk (2008) yang menyatakan bahwa wanita bertato lebih banyak mendapatkan komentar negatif dan masalah stigma di depan umum, tempat kerja, atau sekolah dari pada pria bertato.

Selain tato, fenomena yang mewabah di kalangan perempuan adalah fenomena hijaber. Di kalangan masyarakat saat ini komunitas-komunitas hijabers, disamping sebagai anjuran agama bagi perempuan muslim, hijab juga merupakan sebagai citra diri, representasi fashion masa kini dan gaya hidup. Hijab modern dinilai lebih fleksibel dan dapat dikombinasikan dengan berbagai busana lain. Meningkatnya minat wanita muslim untuk berhijab diiringi dengan munculnya berbagai merek busana muslim menjadi salah satu faktor sehingga menjadikan hijab sebagai tren fashion di kalangan wanita muslim. Berdasarkan data dari Kemenparekraf yang dirilis tahun 2012, dari 14 sektor ekonomi, fashion dan kerajinan memiliki pertumbuhan paling pesat. Setiap tahun, pertumbuhannya mencapai tujuh persen. Hampir tujuh miliar dollar yang disumbangkan oleh industry fashion, dan mengalami peningkatan dua sampai tiga persen dari sisi ekspor, dan busana muslim menjadi salah satu penyumbang terbesar untuk pertumbuhan ekonomi (Hadi, 2015 dalam Widyawati, 2016).

Berbeda halnya dengan hijab yang identik dengan perempuan muslimah sejati, fenomena kontroversial terjadi dan bertolak belakang dengan stigma hijab belakang ini dengan adanya seorang gadis dengan tato di dahi mendadak menjadi perhatian warganet melalui foto-foto yang diunggahnya ke media sosial. Gadis yang dulunya anak punk memutuskan untuk berhijrah dari masa lalunya dan kini muncul dengan penampilan berhijab. Dia adalah Iska Randy gadis, belia yang tubuhnya dihiasi tato, tak terkecuali wajahnya. Tato besar pada jidat sebelah kanan semakin menegaskan jika ia dulunya seorang punker. Namun begitu, Iska mengaku sudah bertobat dan ingin membuka lembaran baru dalam hidupnya. Dalam akun Instagramnya @iskarandy, ia bahkan meminta doa dan dukungan kepada netizen agar dirinya mampu istiqomah dalam niat untuk berubah seutuhnya (Okezone, 2018).

Menanggapi segala teori dan beberapa penelitian terdahulu yang telah diuraikan di atas seakan bertolak belakang dengan munculnya fenomena Iskarandiny mantan perempuan punk yang viral di media sosial Instagram yang membagikan fotonya berhijab dengan banyak tato. Hal langka yang terjadi yakni hijab yang biasanya identik dan mencerminkan karakter perempuan muslimah dan ciri khas keislaman wanita, berbeda pada kasus Iskarandiny yang kini berhijab tetapi wajahnya sebagian dipenuhi dengan tato. Hal ini tentu merupakan suatu fenomena didalam masyarakat dan juga menimbulkan banyak makna dan perdebatan antara tato dan hijab. Berdasarkan uraian diatas peneliti tertarik untuk melakukan penelitian tentang "Makna Citra Diri Perempuan Bertato dan hijab". Adapun rumusan masalah dalam penelitian ini yaitu bagaimana komunikasi dan makna citra diri perempuan bertato dan perempuan berhijab. Penelitian ini bertujuan untuk mengetahui makna citra diri perempuan bertato dan perempuan berhijab. 


\section{Metode Penelitian}

Jenis penelitian ini adalah kualititatif deskriptif, yaitu jenis penelitian yang menjelaskan atau menggambarkan suatu fenomena, dalam hal ini citra diri perempuan hijab bertato. Adapun strategi yang digunakan dalam penelitian adalah fenomenologi karena penelitian terkait fenomena sosial. Sasaran penelitian ini mengambil mahasiswi yang mengenakan hijab dan mahasiswi/ non mahasiswi yang menggunakan tato karena peneliti ingin mengetahui dari dua sudut pandang dan bagaimana mereka memaknai citra diri perembuan berhijab dan bertato sekaligus seperti iskarandiny. Langkah-langkah pengumpulan data meliputi usaha membatasi penelitian, mengumpulkan informasi melalui observasi, wawancara, dan dokumentasi. Teknik analisis data yang digunakan dalam penelitian ini adalah pengumpulan data, reduksi data, display data, verifikasi dan penegasan kesimpulan. Keabsahan data dalam penelitian ini menggunakan teknik triangulasi.

\section{Hasil Temuan dan Diskusi}

Berdasarkan hasil wawancara peneliti dengan dua orang informan, Deva dan Virda. Setiap subyek atau individu (perempuan bertato) pasti mempunyai alasan tersendiri dalam memutuskan untuk memakai tato pada tubuhnya. Alasan-alasan tersebut tidak bisa dipisahkan dari makna tato bagi perempuan bertato tersebut sekalipuan telah mengenakan hijab. Pemaknaan atas diri sendiri yang dilakukan oleh perempuan berhijab dan bertato ini masuk dalam konsep pemikiran Erving Goffman, yaitu konsepsinya tentang Self, menurut Goffman ialah sebuah kode yang membuat pemahaman atas seluruh aktifitas individu dan memberikan dasar untuk mengorganisirnya. Self ini dapat dipahami tentang individu dengan melihat pada tempat yang ia ambil dalam organisasi di aktivitas sosialnya, sebagai penegasan atas pernyataan sikap individu tersebut. Individu, bagaimanapun juga dipaksa oleh masyarakat untuk menunjukan sebuah bentuk "ia dapat bekerja" atau dengan kata lain berusaha untuk membuat dirinya diterima oleh masyarakat (Lemert dan Branaman, 2017: viii). Self sangat berhubungan dengan pemikiran seorang individu, yaitu bagaimana ia memandang dan memaknai dirinya, termasuk kontribusi pemikiran dari orang lain mereka.

Hampir setiap informan, Virda dan Deva, mempunyai pemaknaan yang sama tentang diri mereka sendiri. Mereka memaknai diri mereka sebagai perempuan yang sangat mencintai seni tato bukan perempuan yang sedang mencari jati diri baru yang selalu identik dengan perbuatan negatif. Bagi mereka perbuatan negatif yang perbedaan anggapan sering terjadi diantara perempuan bertato dengan lingkungan sekitarnya. Pemaknaan yang dimaksud dalam hal ini adalah bagaimana perempuan bertato ini memaknai dirinya sendiri.

Baik Deva dan Virda pun sadar jika pemaknaan diri mereka mempunyai perbedaan dengan pendapat maupun anggapan yang muncul di sekeliling mereka. Deva dan Virda menganggap jika manusia tidak bisa menentukan apakah perbuatan yang telah mereka lakukan itu adalah salah dan berdosa. Pada konsepsi self ini perempuan bertato juga mempunyai keinginan untuk menunjukkan pada lingkungan di sekitarnya tentang apa yang bisa mereka lakukan dan perbuat. Deva dan Virda menjelaskan jika mereka juga bisa berprestasi dan sebagai perempuan bertato juga mengetahui apa yang menyebabkan perbedaan ini muncul. Pada temuan data telah diketahui jika mereka sebagai perempuan bertato selalu dihadapkan dengan 
persoalan berupa hambatan baik itu dari norma, nilai agama,dan budaya. AJ,AD, dan SR pun sepakat jika hambatan yang paling keras adalah norma dan budaya.

Adanya tato yang dimiliki baik Deva maupun Virda, mempengaruhi citra diri individu. Tato dalam masyarakat memiliki label yang negatif terlebih jika dimiliki oleh perempuan. Baik Deva dan Virda pun sadar jika pemaknaan diri mereka mempunyai perbedaan dengan pendapat maupun anggapan yang muncul di sekeliling mereka. Kedua informan menganggap dan berpandangan jika manusia tidak bisa menentukan apakah perbuatan yang telah mereka lakukan itu adalah salah dan berdosa. Dalam hal ini, kedua informan telah memiliki perceptual component yang mana keduanya menyadarai penampilan masing-masing dan tentu akan berdampak terhadap orang lain yang melihat. Pada konsepsi self ini perempuan berhijab dan bertato juga mempunyai keinginan untuk menunjukkan pada lingkungan di sekitarnya tentang apa yang bisa mereka lakukan dan perbuat. Mereka sebagai perempuan berhijab dan bertato juga mengetahui apa yang menyebabkan perbedaan ini muncul. Pada temuan data telah diketahui jika mereka sebagai perempuan berhijab dan bertato selalu dihadapkan dengan persoalan berupa hambatan baik itu dari norma, nilai agama,dan budaya sekalipun mereka telah mengenakan hijab layaknya muslimah pada umumnya. Deva dan Virda pun sepakat jika hambatan yang paling keras adalah norma dan budaya yang masih dinilai kurang memberikan dampak baik meskipun Deva dan Virda kini berhijab.

Adapun conceptual component, kedua informan sepakat apabila seseorang melihat dirinya yang tengah berhijab namun memiliki tato tentu memiliki pandangan tersendiri. Deva yang memiliki tato, beberapa di tangan juga tidak luput dari komentar-komentar orang lain baik di lingkungan sekitar maupun di media sosial Instagram, sebab tato yang dimiliki memberikan ciri khas. Deva tidak masalah dengan komentar-komentar tersebut karena beberapa komentar juga menunjukkan komentar yang positif dan tidak melabeli Deva. Adapula yang mendukung Deva untuk terus mendalami Islam dengan baik sekalipun memiliki tato. Hal itu dikarenakan baik norma maupun budaya sangat berkaitan erat dengan lingkungan dan masyarakat. Norma dan budaya bisa dikatakan sebagai salah satu alat kontrol sosial yang ada pada lingkungan masyarakat di mana subjek (perempuan bertato dan berhijab) itu tinggal. Sedangkan nilai yang terkandung dalam agama menurut Deva dan Virda tidak menjadi hambatan yang utama dikarenakan nilai agama merupakan hubungan pribadi yang terjadi di antara Tuhan dengan diri mereka masing-masing. Deva dan Virda menganggap jika manusia tidak bisa menentukan apakah perbuatan yang telah mereka lakukan itu adalah salah dan berdosa.

Aspek terkahir dalam citra diri yakni Attitudional Component yang merupakan pikiran dan perasaan seseorang mengenai dirinya. Dalam hal ini peneliti menanyakan kepada kedua informan tanggapan orang terdekat mengenai tato yang dimilikinya yaitu tanggapan orang tua kedua informan sepakat jika orang tua tentu menolak dan memberi respon negatif ketika melihat anaknya memiliki tato. Bahkan Virda menambahkan jika penolakan orang tua terhadap keputusannya mentato juga membuat dirinya kabur dari rumah untuk beberapa saat. Namun, baik Deva dan Virda melihat reaksi orang tua seperti itu juga menimbulkan gejolak dan penyesalan tersendiri hingga akhirnya memutuskan untuk berhijab dan taubat ke arah yang lebih baik. Dalam hal ini, perempuan berhijab dan bertato benar-benar ingin diakui sebagai perempuan yang jangan dilihat dari kaca mata negatif saja. Walaupun sosok perempuan bertato selalu dianggap melawan norma, nilai agama, dan budaya akan 
tetapi mereka tetap dengan sekuat tenaga untuk berperilaku sesuai dengan apa yang diharapkan.

\section{Simpulan}

Stigma yang selalu diperoleh oleh perempuan bertato pada penelitian ini adalah dimana perempuan bertato selalu dianggap perempuan yang erat dengan hal negatif. Selain itu beberapa masyarakat juga menganggap jika perempuan bertato itu sebagai individu yang merugi. Hal itu dikarenakan sebagian masyarakat masih menganggap jika keputusan perempuan mentato tubuhnya itu adalah suatu keputusan yang sia-sia karena tato dianggap merusak tubuh bukan memperindah tubuh. Selain itu, anggapan sering juga dijumpai jika perempuan bertato dianggap perempuan yang tidak layak atau tidak bisa menjalankan ibadah. Hal itu dikarenakan perempuan bertato masih saja dianggap sebagai perempuan yang tidak suci yang disebabkan karena tato yang melekat pada tubuhnya.

Fenomena baru yakni perempuan berhijab dan bertato saat ini telah menjadi salah satu polemik pada kehidupan masyarakat. Meskipun tato merupakan salah satu karya seni yang seharusnya tidak ada batasan dalam menikmatinya, akan tetapi dikarenakan selalu berbenturan norma, budaya, dan nilai agama. Tato hingga saat ini bagi sebagian masyarakat adalah hal yang tabu untuk dimiliki oleh perempuan.

Perempuan bertato selalu dianggap perempuan yang identik dengan perilaku negatif. Perempuan bertato dan mengenakan hijab memiliki pemaknaan dan citra diri tersendiri di dalam masyarakat. Adanya tato yang dimiliki menimbulkan citra diri perempuan menjadi negatif sekalipun telah berhijab dan juga berdampak terhadap komentar-komentar pro dan kontra. Sejauh pengamatan dan pemaparan hasil wawancara informan penelitian, para informan sepakat jika mentato tubuh merupakan hal yang negatif baik dari segi pemikiran diri sendiri maupun pandangan orang lain sehingga memutuskan untuk berhijab.

Dari penelitian ini juga dapat disimpulkan jika reaksi perempuan bertato yang menggunakan hijab atas stigma dan perilaku diskriminatif yang sering di dapatkan pada saat berinteraksi dengan lingkungan sekitarnya adalah selalu memberikan penjelasan ke pada publik jika perempuan bertato itu bisa berprestasi dan bekerja keras. Penjelasan tersebut tidak hanya berupa janji tetapi juga disertai bukti yang nyata. Tato bagi mereka adalah seni yang bisa dimiliki siapa saja seperti halnya menikmati musik, drama, dan kesenian lainnya. Perbedaan cara pandang mengenai seni tato menurut mereka hanya masalah perbedaan selera dalam menikamati sebuah karya seni.

\section{Daftar Pustaka}

Adhisty Anindita Ferani, dkk. (2015). Hubungan antara Citra Tubuh dan Konsep Diri dengan Motivasi Bertato pada Wanita di Surakarta. Jurnal Ilmiah Psikologi Candrajiwa Vol 4, No 3 Des (2015) ISSN:2442 8051.

Adhitya Nugraha. (2016). Fenomena Komunikasi Remaja Perempuan Bertato di Pekanbaru. JOM FISIP, Vol. 3 No. 2 - Oktober 2016.

AW Suranto. (2011). Komunikasi Interpersonal. Yogyakarta: Graha Ilmu

Ayu Liza Karunia Syachrizally, Widayatmoko. (2018). Gaya Hidup Remaja Perempuan dalam Membentuk Body Image dan Citra Diri Sesuai Tren Masa Kini. https://journal.untar.ac.id/index.php/koneksi E-ISSN : 2598 - 0785. 
Bayu Tria Firwansyah Putra. (2016). Fenomena Jilboobs di Media Sosial (Analisis Semiologi Tentang Makna Visual Pada Fenomena Busana Hijab "Jilboobs"e di Media Sosial Instagram). Jurnal: digilib.uns.ac.id.

Cangara, Hafied (2012). Pengantar Ilmu Komunikasi. Jakarta: PT. Raja Graffindo Persada.

Effendy, Onong Uchjana. (2016). Ilmu Komunikasi, Teori dan Praktek. Bandung: Rosdakarya.

Fatmawati,dkk. Stigmatisasi dan Perilaku Diskriminatif pada Perempuan Bertato. (2015). Jurnal Equilibrium Pendidikan Sosiologi FKIP Unismuh Makassar, Volume III No. 1 November 2015.

Fristy, "Citra Diri pada Remaja Putri yang Mengalami Kecenderungan Gangguan Body Dysmorphic", Jurnal Skripsi, Fakultas Psikologi, Universitas Gunadarma, Desember 2015.

Jasmia, Wa Ode, dkk. (2015). Transformasi Diri Wanita Berhijab (Studi Fenomenologis Pada Afiliasi-Afiliasi Organisasi Keislaman Di Kota Gorontalo). Jurnal Hasil Penelitian Skripsi Prodi Ilmu Komunikasi.

Kadir Olong, Hatib Abdul. 2013. Tato. Jakarta. PT LKIS Pelangi Aksara.

Komariyah, Fadilah Nur. (2015). Hubungan Antara Persepsi Gaya Hidup Fashion dengan Citra Diri pada Komunitas Hijabers di Surakarta. Naskah Publikasi, Fakultas Psikologi, Universitas Muhammadiyah Surakarta, 2015.

Kurniawati, Puput. (2017). Komunikasi Interpersonal dalam Menjalin Hubungan Perkawinan Adat Ngalor Ngulon (Studi Fenomenologi pada PasanganSuami Istri di Desa Arjowilangun Kecamatan Kalipare Kabupaten Malang) [skripsi]. Malang: Universitas Muhammadiyah Malang.

Lemert, C., \& Branaman, A. (Eds.) (2017). The Goffman Reader. Oxford, UK: Blackwell Publishing.

Maltz, Maxwell. (2010). Kekuatan Ajaib Psikologi Citra Diri. Jakarta: Mitra Utama

Pipit Yuliani, (2013). Hubungan Citra Diri (Self-Image) dengan Perilaku Perawatan Wajah yang Dilakukan Pria di Klinik Skin Care Kota Bandung. Bandung: Universitas Pendidikan Indonesia.

Reza Pahlevy, dkk. (2012). Konstruksi Makna Tato pada Anggota Komunitas "Paguyuban Tattoo Bandung". http://jurnal.unpad.ac.id

Sabrina Adventina Fitrianty Manru. (2017). Tato Sebagai Representasi Spiritual Orang-Orang Bertato. Tesis. Salatiga: Universitas Kristen Satya Wacana

Sendjaja, Sasa Djuarsa. (2014). Pengantar Ilmu Komunikasi. In: Komunikasi: Signifikansi, Konsep, dan Sejarah. Jakarta: Universitas Terbuka.

Sorga Perucha Iful Prameswari, Siti Aisah, dan Mifbakhuddin. (2013). Hubungan Obesitas dengan Citra Diri dan Harga Diri pada Remaja Putri di Kelurahan Jomblang Kecamatan Candisari Semarang. Jurnal Keperawatan Komunitas, Volume 1, No. 1, Mei 2013.

Tri Hariyadi Setya Wardhana,dkk. (2014). Persepsi Mahasiswa Tidak Bertato Terhadap Fenomena Tato di Kalangan Mahasiswa Universitas Brawijaya. Jurnal Unibraw, Vol 2.

Widianti, Yeni. (2017). Hubungan antara Citra Diri tentang Ciri-ciri Perkembangan Seksual Sekunder dengan Konsep Diri pada Remaja Putri di SMP Negeri 33 Semarang [Skripsi]. Semarang: Fakultas Ilmu Keperawatan dan Kesehatan, Universitas Muhammdiyah Semarang. 
Winayu, Irianita Jati (2013) "Body Image Mahasiswa Yang Menggunakan Tato". Jurnal Ilmu Komunikasi Vol 4-115

Wiryanto. (2014). Pengantar Ilmu Komunikasi. Jakarta: PT. Gramedia Widasarana Indonesia

Witri Nur Laila. (2016). KONSEP DIRI REMAJA MUSLIM PENGGUNA BAHASA JAWA KRAMA. Vol.09/N0.02/Oktober 2016 - Profetik Jurnal Komunikasi.

Wiyarsih, Maryatun, dan Joko Santoso. (2015). "Citra Diri Pustakawan di Era Persaingan Bebas (Studi Kasus di Perpustakaan Universitas Gadjah Mada dan Badan Perpustakaan dan Arsip Daerah Provinsi Daerah Istimewa Yogyakarta)". Jurnal Pustakawan Online. Jakarta: Perpustakaan Nasional Republik Indonesia.

Yustinus Semiun. (2016). Kesehatan Mental 1: Pandangan Umum Mengenai Penyesuaian Diri dan Kesehatan Mental serta Teori-teori yang Terkait. Yogyakarta: Penerbit Kanisius 